\title{
The Moderating Effect of Competitive Business Strategy on Corporate Environmental Performance and Corporate Carbon Emission Disclosure Towards Corporate Financial Performance
}

\author{
Yohanes Mardinata Rusli $^{1^{*}} \quad$ Yvonne Augustine $^{2^{*}} \quad$ Etty Murwaningsari ${ }^{2^{*}} \quad$ Ririn Breliastiti ${ }^{3^{*}}$ \\ 1.Trisakti University, PhD Student at Faculty Economics and Business, J1. Kyai Tapa No.1, Tomang - Grogol \\ Petamburan, Jakarta 11440, Indonesia \\ Bunda Mulia University, Lecturer, Jl. Lodan Raya No. 2, Ancol, Jakarta 14430, Indonesia \\ 2.Trisakti University, Jl. Kyai Tapa No.1, Tomang, Grogol Petamburan, Jakarta 11440, Indonesia \\ 3.Bunda Mulia University, J1. Lodan Raya No. 2, Ancol, Jakarta 14430, Indonesia
}

\begin{abstract}
The purpose of this research is to examine the effect of corporate environmental performance and corporate carbon emission disclosure toward corporate financial performance with competitive business strategy as moderating variable. The research design is quantitative methods using secondary data, which is data from the sustainability report of 18 go public companies listed on the Indonesia stock exchange from 2015 to 2017, with 54 units of analysis for the period of 2015-2017. The data analysis used in this research was multiple linear regression with data panel, which is processed by using SPSS. The results show that: (i) corporate environmental performance has a positive and significant effect towards the corporate financial performance; (ii) corporate carbon emission disclosure has not a significant effect towards the corporate financial performance; (iii) competitive business strategy strengthens the effect of corporate environmental performance towards the corporate financial performance; (iv) competitive business strategy has not effect of corporate carbon emission disclosure towards the corporate financial performance. This research contributes to provide the corporate environmental performance literature, corporate carbon emission disclosure literature, and corporate financial performance literature. The results of this study can contribute to making consideration for go public companies to consider whether corporate carbon emission disclosure are needed or not in the direction of the corporate financial performance.

Keywords: Competitive Business Strategy, Corporate Environmental Performance, Corporate Carbon Emission Disclosure, Corporate Financial Performance.
\end{abstract}

DOI: $10.7176 / \mathrm{JESD} / 10-6-13$

Publication date:March $31^{\text {st }} 2019$

\section{INTRODUCTION}

Some of the extreme climate changes or weather often occur throughout the world in recent years. This directly makes the public focus and increase the level of awareness of the climate change that occurs. Climate change that occurs in several countries in the world can lead to global warming. Global warming is a hot issue and has become a public focus to be discussed in several forums of world organizations in the recent decades. Global warming can be caused by the main factor being carbon emissions (Choi et al., 2013; Kumarasiri \& Jubb, 2016; and Paul et al., 2017)

Global warming is now becoming an increasingly important business problem for some countries, not just developed countries, but now developing countries have also given special attention to the response that must be made in the face of obstacles from global warming produced by carbon emissions. According to Luo et al., 2013, disclosure of the company's carbon emissions for developing countries is still optional, so it has not become an obligation for companies in developing countries so that developing countries disclosure of their company's carbon emissions is still voluntary, not yet an acknowledgment which is mandatory.

In the literature on the field of accounting, the disclosure of carbon emissions is a new concept which has been conducted in recent years by many researchers in the accounting field. Research on the topic of disclosure of carbon emissions has been carried out by several researchers in the field of accounting, such as the research conducted by Giacomo et al. (2017); Kumarasiri and Jubb (2016); Jiang and Chen (2016); Hsu and Lin (2015), Renukappa et al. (2013); Choi et al. (2013); Ghomi and Leung (2013). Disclosure of carbon emissions carried out by an entity has several challenges caused by the threat of global warming. One of the challenges that an entity needs to understand and communicate is its contribution to global warming from its carbon emissions (Choi et al., 2013 and Luo et al., 2014).

According to several studies conducted on disclosure of company carbon emissions, such as research conducted by Ranukappa (2013); Choi et al. (2013); Bae \& Liu (2013); and Kumasiri \& Jubb (2016), which prove scientifically that the activities of companies that are the sample in the study are directly related to the existence of climate change caused by global warming. According to Bae and Liu (2013), the global warming that occurs is what makes an environmental institution both the government and non-governmental institutions begin to pay 
attention to social impacts and environmental impacts. Based on its influence on social impact and its environmental impact, make the environmental institution to urge companies to reduce their company's carbon emissions with the intention of helping the institution's commitment in reducing carbon emissions.

Research on the disclosure of carbon emissions by companies with the company's financial performance has been done before, namely: Sudibyo (2018); Soewarno (2018); Rahman et al. (2014). Many companies, especially in developed countries, have disclosed carbon emissions with volountary disclosure, meaning that without being asked by the government, they have voluntarily disclosed their carbon emissions with the intention of improving their financial performance. Companies that make disclosures on carbon emissions also have the goal of participating in the government's commitment to safeguarding climate change that is happening in the world. . With the disclosure of carbon emissions, the company also expects that the resulting product will be the first choice of consumers who will consume these products

In an effort to improve the company's financial performance, the company carries out several business strategies so that the consumers want to buy and use products and services produced by the company (Jiang and Chen, 2016). According to research Jiang and Chen (2016), the company's strategy to increase its advantage in order to improve the company's financial performance, it can't be separated by following the strategy of behavior corporate customers with their demand for products that are sensitive to carbon emissions. Companies in implementing the company's carbon emission strategy to manage the company's carbon emissions which will be disclosed in the company's carbon emissions disclosure report require sufficient knowledge about the company's carbon emission reduction activities (Hsu and Lin, 2015).

The purpose of this research is to examine the influence of corporate environmental performance and corporate carbon emission disclosure on corporate financial performance with competitive business strategy as moderating variables. This study uses the competitive business strategy variable as a moderating variable, which is the novelty of this study.

This research also contributes to the management of the company to know that with the knowledge of reducing carbon emissions obtained by the management of the company can increase management's intention in disclosing the company's carbon emissions, so the company that initially voluntary disclosure will with awareness and intention to make mandatory disclosures in disclosure of company carbon emissions.

\section{LITERATURE REVIEW}

\subsection{Stakeholder Theory}

According to Stakeholder theory, a company is not an entity that only operates for its own sake, but must also be able to provide benefits to stakeholders. That way, the existence of a company can be influenced by the support provided by stakeholders of the company. According to Gray et al. (1995) state that social responsibility and environmental responsibility are the responsibility of the business world to be accountable to all stakeholders. So that the responsibility is not only limited to responsibility for shareholders only.

The application of stakeholder theory has been applied to analytical and empirical analysis of the company and its operating environment, a stakeholder model based on critical realist theory of differentiation and social change. Unlike some social constructs of reality theory, rules, structures, and cultural systems are treated analytically differently from perceptions of them, or actions taken through them (Friedman and Miles, 2002). Stakeholders argue that social structures (travel plans, interests, roles, opportunities, differences in strength) and cultural systems (some thoughts about what is right or wrong depends on predictable universal laws of logic) shape one's actions, perceptions of thoughts and efforts to influence thinking and the actions of others. Such actions can have an impact on the further development of social structures and cultural systems.

\subsection{Legitimacy Theory}

A legitimacy theory is a theory that focuses on the relationship between companies and society through regulations made by the government. According to Gray et al. (1996), that a disclosure has a role in bridging a company with a group of people. The company has the intention to be able to recognize its legitimacy from a group of people, because the company wants to be able to convince the community that the company's business activities are in accordance with the norms and standards in the applicable provisions (Deegan and Unerman, 2006). Recognition for the legitimacy of a company can be obtained by a company if the company and the community that has the relationship can have the same expected results. This is to reduce the risk in the long term of the demands of the community at any time if the company violates the norms and standardization set by the government (Deegan et al. 2002).

\subsection{Corporate Environmental Performance and Corporate Financial Performance}

The environment that must be taken into account for its sustainability so that the ecosystem in this island can continue to live, then environmental performance is one of the factors that must be fulfilled by the company to participate in maintaining the preservation of their environment. In addition, maintaining and preserving the 
environment is a necessity that the company cannot negotiate with. This is because there is some pressure from the government as a regulator that has the highest authority and several community institutions that care about the environment (Soewarno, et al. 2018). According to research conducted by Porter and Linde (1995), improving environmental performance is an important source of information for companies to achieve efficient production levels, increase productivity in accordance with safety standards, reduce costs caused by environmental degradation and opportunities to find new markets.

According to several studies that analyzed the effect of corporate environmental performance on corporate financial performance conducted by Manrique and Ballester (2017), Soewarno et al. (2018), and Dobre et al. (2015) stated that corporate environmental performance has a significant positive effect on corporate financial performance. Meanwhile, according to research conducted by Iwata and Okada (2010), states that corporate environmental performance has no significant influence on the corporate financial performance.

Based on several studies influence opinion regarding corporate environmental performance of the corporate financial performance that has been done by some researchers that has been described above, in this thesis research using the following hypotheses:

$\mathrm{H}_{1}$ : Corporate Environmental Performance positive significant effect on corporate financial performance

\subsection{Corporate Carbon Emission Disclosure and Corporate Financial Performance}

The discussion on topics relating to carbon emission disclosure with corporate financial performance is an interesting thing to do research at this time. This is interesting, because the responsibility carried out by the company towards the environment does not only revolve around the company but to help the government's commitment in reducing global carbon emissions. Responsibility for the environment around the company is directly related to the company's financial performance. According to several studies that analyzed the effect of corporate carbon emission disclosure on corporate financial performance conducted by Soewarno et al. (2018) and Rahman et al. (2014) stated that corporate carbon emission disclosure has a significant positive effect on corporate financial performance. Meanwhile, according to research conducted by Ganda \& Milondzo (2018) and Liu et al. (2016), states that corporate environmental performance has a significant negative effect on the corporate financial performance.

$\mathrm{H}_{2}$ : Corporate carbon emission disclosure positive significant effect on corporate financial performance

\subsection{Corporate Environmental Performance, Competitive Business Strategy, and Corporate Financial Performance}

Research and development carried out by Porter (1985) developed a framework that outlines how companies can choose business strategies to compete effectively in existing business competition. He argues that companies must emphasize that the essence of a company's business strategy is its ability to intentionally choose a series of activities that will provide a unique mix of values to its customers (Jermias, 2008). According to several studies that analyzed the effect of corporate carbon emission disclosure on corporate financial performance conducted by Rahimi et al. (2016) and Al-Rdaydeh et al. (2018) stated that competitive business strategy strengthens the influence between corporate environmental performance and corporate financial performance.

$\mathrm{H}_{3}$ : Competitive business strategy strengthens the influence between corporate environmental performance and corporate financial performance.

\subsection{Corporate Carbon Emission Disclosure, Competitive Business Strategy, and Corporate Financial Performance}

Corporate carbon emissions disclosure is forcing companies to disclose correctly, which requires a transparency attitude of the company's management in disclosing the company's carbon emissions. According to a study conducted by Fenster (2015), transparency is an act that is not covered up in carrying out all of the company's business activities. This openness can be in the form of information and communication openness that must be carried out by the company. In order to improve the company's financial performance by disclosing the company's carbon emissions, the company will adopt a more competitive business strategy. In the Al-Rdaydeh et al. (2018), competitive business strategy as a moderating variable strengthens the influence of financial leverage on the company's financial performance.

The business strategy will also increase the influence of disclosure of company carbon emissions from the company's financial performance (Peng et al. 2014), where in this study competitive business strategy is a moderating variable between corporate carbon emission and corporate financial performance.

$\mathrm{H}_{4}$ : Competitive business strategy strengthens the influence between corporate carbon emission disclosure and corporate financial performance.

\section{Research Methods}

The research population is all public companies listed on Indonesian Stock Exchange with published the 
sustainability report for the period of 2015-2017. The public companies of published the sustainability report because it has a carbon emission disclosure and has many listing companies with various data. The techniques of determining the samples is purposive sampling with criteria: (1) the companies listed in IDX during 2015-2017; (2) The company issued financial statements and sustainability report for the period ended December 31 ; (3) the company published a complete data in the form of financial reports and sustainability report for the period of 2015 2017. The reason of using period of 2015-2017 is that the data of these three years are available and can be accessed by public. A total of 26 companies (78 observation) can be analyzed for this research.

\subsection{Variable and Measurement} Corporate Financial Performance

The performance of an organization's financial statements must be increased especially for companies that are looking for profit. Measuring the performance of a company's financial statements can be measured by measuring profitability ratios, where one measure is used to measure management performance in managing corporate wealth. Profitability is measured using one of the indicators contained in profitability ratios, namely return on assets (ROA). By comparing net income with total assets. According to Manrique and Ballester (2017), ROA can be measured by the formula:

\section{Net Incomes

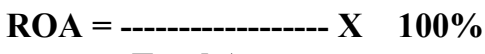 \\ Total Asset \\ Corporate Carbon Emission Disclosure}

Corporate carbon emission disclosure used for this research is Choi et al. (2013) measurement, which measures the carbon emission by developing a broad disclosure of carbon emissions with a checklist based on the information request sheet regarding Corporate Carbon Emission Disclosure, which measures using a score on each item of disclosure of Carbon Emission Checklist with a dichotomy scale. Every checklist item has a value of 1 (one), so that if the company disclosure can be carried out in full all the disclosure items will be worth 18, so add the checklist score of each company conducted by the research.

Every checklist items of activities in disclosure of carbon emissions in this study are divided into 5 categories. It can be explained that, if the company discloses items in accordance with what is determined by the Carbon Disclosure Project (CDP) it will be given a score of 1, whereas if the items specified are not disclosed they will be given a score of 0 . Furthermore, the score 1 is added together and divided by the number the maximum items that can be disclosed are multiplied by $100 \%$.

The formula for disclosure of carbon emissions in this study is determined based on the formula equation as follows. CCED $=\left(\sum \mathrm{di} / \mathrm{M}\right) \times \mathbf{1 0 0} \%$

Notes:

$\mathrm{CCED}=$ Disclosure of company carbon emissions; $\sum \mathrm{di}=$ Total overall score 1 that the company gets; $\mathrm{M}=$ Maximum item total that can be disclosed (23 items)

\section{Corporate Environmental Performance}

Measurements of environmental performance carried out by companies can be seen from environmental performance measurements that use the results of the PROPER assessment as an indicator of the company's environmental performance. PROPER is a company environmental performance assessment program developed by the State Ministry of Environment. The Ministry of Environment and Forestry of the Republic of Indonesia (2015) provides several categories to obtain the colors provided in PROPER, including: (1) Gold: has carried out more than required environmental management and has made efforts to 3R (Reduce, Reuse, Recycle), implement a system of sustainable environmental management and make efforts that are useful for the interests of the community in the long term; (2) Green: has carried out environmental management more than required, has an environmental management system, has a good relationship with the community, including making efforts to $3 \mathrm{R}$ (Reduce, Reuse, Recycle); (3) Blue: has made environmental management efforts that are required in accordance with applicable regulations or regulations; (4) Red: make efforts to manage the environment, but only partially achieve results in accordance with the requirements as stipulated in the legislation; (5) Black: not making efforts to manage the environment means, intentionally not making environmental management efforts as required and potentially polluting the environment. The measurement in this study uses a scale of 0 to 5 according to the type of color in PROPER

\section{Competitive Business Strategy}

Companies can be classified into strategic types of business using the Porter framework (1985). As noted, researchers have succeeded in utilizing Porter's typology to classify the company's business strategy in order to improve the company's financial performance because the company has the advantage of the company's business. The classification of the company's business strategy is based on Porter's strategy (1985). Thus the company's business strategies can be categorized into two groups: cost leadership strategies and product differentiation strategies (Rahimi, 2016). However, this study is limited to only measuring cost leadership strategies, calculated 
as follows:

\section{Total Sales \\ Com_BusStra = - ------------ X $100 \%$}

Research Model

Research model based on the Research Hypothesis are as follows:

$1^{\text {st }}$ regression model to test hypotheses 1 and 2:

Cor_FinPer $=\beta 0+\beta 1$ Cor_EnvPerf $+\beta 2$ Cor_CarEm $+\varepsilon$

model 1

$2^{\text {nd }}$ regression model to test hypotheses 3 and $\overline{4}$ :

CCE_Disc $=\beta 0+\beta 1$ Cor_EnvPerf $+\beta 2$ Cor_CarEm $+\beta 3$ Comp_BusStra $+\beta 5$ Cor_EnvPerf*Com_BusStra $+\beta 6$

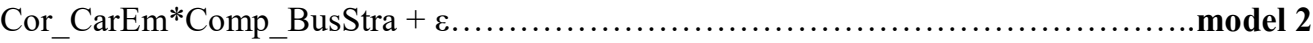

Where, Cor_FinPer: Corporate Financial Performance; Cor_EnvPerf: Corporate Environmental Awareness; Cor_CarEm: Corporate Carbon Strategies; Comp_BusStra: Competitive Business Strategy.

Data Analysis

The data are analyzed using SPSS version 24.0. The hyphotesis or significant test is done with multiple regression, namely by compering significant with $\alpha$. If sig. or $p$-value is less than $\alpha$; then statistical significant is attained. The coefficient of determinant is used to measure the ability of independent variabel to prodict a dependent variable in this research.

\section{Result and Discussions \\ Descriptive Statistics}

Table 1

\begin{tabular}{|c|l|l|l|l|l|}
\hline \multicolumn{7}{|c|}{ Descriptive Statistics } \\
\hline & $\mathrm{N}$ & Minimum & Maximum & Mean & Std. Deviation \\
\hline Cor_FinPerf & 54 & -4.75000 & 38.16000 & 8.4098148 & 8.38876686 \\
\hline Cor_EnvPerf & 54 & .17391 & 89913 & .5145609 & .17744284 \\
\hline Cor_CarEm & 54 & 2.00000 & 5.00000 & 3.6111111 & .65636698 \\
\hline Cor_BusStra & 54 & .00470 & 2.39190 & .7418315 & .47740483 \\
\hline Valid N (listwise) & 54 & & & & \\
\hline
\end{tabular}

Source: Output SPSS Version 24.0

The descriptive statistics in table 1, show that the corporate carbon emission disclosure has a relatively lower than standard deviation value compared to the mean. This indicated that sample for corporate structure is quite low. Each variable of corporate environmental performance and competitive business strategy, the standard deviation value is lower than the mean, but the difference is relatively small. This means that this data indicates good results because the smaller the value of the standard deviation, the data or variable is more evenly distributed, meaning that the standard deviation is not far from the average (mean).

\section{Normality Test}

The Normality Test uses the Kolmogorov One-Sample Test - Smirnov Test. with a level of $\alpha=5 \%$. Determination of the normality test is based on the asymp.sig value obtained. If the value is asymp.sig. (2-tailed) above or equal to 0.05 , then Ho cannot be rejected which means the regression model is normally distributed. But if the value of asymp. Sig. (2-tailed) is below 0.05, then Ha cannot be rejected which means the regression model is not normally distributed. A good regression model is a regression model that is normally distributed (Ghozali, 2016).

Table 2

Normality Test P-Plot

\begin{tabular}{|c|c|c|}
\hline Model & Assym. Sig. (2-tailed) & Conclusions \\
\hline 1 & 0,207 & normally distributed \\
\hline
\end{tabular}

Source: Output SPSS Version 24.0

\section{Autocorrelation Test}

The autocorrelation test aims to test whether in the linear regression model there is a correlation between the confounding errors in period $t$ and the interfering errors in the $t-1$ period. (Ghozali, 2016)

Table 3

Autocorrelation Test

\begin{tabular}{|c|l|l|}
\hline Model & Sig. & Conclusions \\
\hline 1 & 0,054 & autocorrelation do not occur \\
\hline
\end{tabular}

Source: Output SPSS Version 24.0

In the previous test data used in this study experienced autocorrelation. To overcome the problem of autocorrelation, the data transformation using Natural Logarithm is carried out according to the directions. Based on the results of the autocorrelation test in table 3 , it can be seen that the sym asymp value is 0.054 . This value is greater than the significance used at 0.05 . Then it can be concluded that after data transformation, random residuals 
or autocorrelation do not occur.

\section{Multicollinearity test}

Multicollinearity test aims to test whether the regression model is found to have a correlation between independent variables. A good regression model should not have multicollinearity between independent variables. The common cutoff value used to indicate the presence of multicollinearity is the Tolerance value $\leq 0.10$ or equal to the VIF value $\geq 10$. If the tolerance value is above 0.1 and the Variance Inflection Factor (VIF) is below 10, it can be concluded that there is no multicollinearity between independent variable. However, if the tolerance value is below 0.1 and the Variance Inflection Factor (VIF) is above 10, then there is a multicollinearity between independent variables.

Table 4

Multicollinearity test

\begin{tabular}{|l|l|l|l|}
\hline Variabel & Tolerance & VIF & Conclusions \\
\hline Cor_EnvPerf & 0,917 & 1,090 & does not occur multicollinearity \\
\hline Cor_CarEm & 0,917 & 1,090 & does not occur multicollinearity \\
\hline
\end{tabular}

Source: Output SPSS Version 24.0

From table 4 above, the results of the Tolerance value on the dividend policy, debt policy, and profitability results show that there is no less than 0.1 , then the VIF value in these variables shows that there are no more than 10. These results indicate that all variable does not occur multicollinearity.

Heteroscedasticity Test

Heteroscedasticity test aims to test whether in the regression model variance inequality occurs from one residual to another observation (Ghozali, 2016).

Table 5

Heteroscedasticity test

\begin{tabular}{|l|l|l|}
\hline Variabel & Sig. & Conclusions \\
\hline Cor_EnvPerf & 0,903 & no symptom of Heteroscedasticity \\
\hline Cor_CarEm & 0,100 & no symptom of Heteroscedasticity \\
\hline
\end{tabular}

Source: Output SPSS Version 24.0

If the significance value (Sig.) $>0.05$ then there is no symptom of Heteroscedasticity. From the output above, it appears that the three variables have no symptoms of heteroscedasticity due to Sig. $>0.05$.

\section{Correlation Test and Determination Coefficient}

The coefficient of determination shows the magnitude of the influence of the independent variables namely dividend policy, debt policy, managerial ownership, firm size and profitability on the value of the company in the entity which includes the consumer goods manufacturing sector in the period 2013 to 2016 as shown in table 6 below.

Table 6

Correlation Test and Determination Coefficient

\begin{tabular}{|c|c|l|}
\hline Model & $\mathrm{R}$ & Adjusted R-Square \\
\hline 1 & 0,835 & 0,661 \\
\hline
\end{tabular}

Source: Output SPSS Version 24.0

The correlation test results in table 6 show that the value of $R$ obtained is positive which is equal to 0.835 . The $R$ value obtained in this study is greater than 0.5 which indicates that there is a strong and positive relationship between corporate environmental performance and corporate carbon emission disclosure with corporate financial performance.

F Test

The results of the $\mathrm{F}$ test can be seen in table 7 below

\begin{tabular}{|c|c|c|c|}
\hline \multicolumn{4}{|c|}{$\begin{array}{l}\text { Table } 7 \\
\text { F Test }\end{array}$} \\
\hline Model & $\mathrm{F}$ & Sig. (2-tailed) & Conclusions \\
\hline 1 & 41,530 & 0,000 & Model regresi fit \\
\hline
\end{tabular}

Source: Output SPSS Version 24.0

Table 7 above shows the $F$ value of 41,530 and the sig value. (2-tailed) obtained at 0,000 which means the value of sig. (2-tailed) below 0.05 . This means that Ha cannot be rejected which means that the regression model is feasible and appropriate to be used in research. 
The Results of Hypothesis 1 and Hypothesis 2

Table 8. The Effect of environmental awareness and corporate carbon strategies on corporate carbon emission disclosure

Cor_FinPer $=\alpha_{0}+\beta_{1}$ Cor_EnvPerf $+\beta_{2}$ Cor_CarEm $+\varepsilon$

\begin{tabular}{|c|c|c|c|c|}
\hline \multirow{3}{*}{ Variables } & \multirow{3}{*}{ Prediction } & \multicolumn{3}{|c|}{ Model 1} \\
\hline & & \multicolumn{3}{|c|}{ Corporate Financial Performance } \\
\hline & & Coefficients & $\mathrm{p}$-value & Hypotheses Status \\
\hline Cons & & 1.327 & 0.000 & \\
\hline Cor_EnvPerf & + & 0.163 & $0.025 * *$ & Significant $\left(\mathrm{H}_{1}\right.$ support $)$ \\
\hline Cor_CarEm & + & -0.041 & $0.068 * *$ & Significant $\left(\mathrm{H}_{2}\right.$ not support $)$ \\
\hline Adjusted R2 & & 0.714 & & \\
\hline F-Statistic & & 41.530 & & \\
\hline Prob (F-Statistic) & & $0.000 * * *$ & & \\
\hline
\end{tabular}

***Significant at a level of 1 percent; **Significant at a level of 5 percent; *Significant at a level of 10 percent

Note: Cor_FinPer: corporate financial performance; carbon emission disclosure; Cor_EnvPerf: corporate environmental performance; Comp_BusStra: competitive business strategy.

Table 3 shows that the effect of corporate environmental performance towards corporate financial performance shows positive and significant result and support hypotheses 1 and hypotheses 2 . This shows that the decision maker in company will be able doing corporate environmental performance to provide corporate financial performance. This result support Soewarno et al. (2018), Manrique and Ballester (2017), Dobre et al. (2015) and Cai, et al. (2014), where companies that carry out activities related to corporate environmental performance will increase the corporate financial performance. The implementation of the company's strategy can also make companies in disclosing their company's environmental performance will increase the company's financial performance with profitability companies.

The Result of Hypotheses 1 and Hypotheses 2

$\mathrm{Q} 1=\alpha_{0}+\beta 1$ Cor_EnvPerf $+\beta 2$ Cor_CarEm $+\varepsilon$

$\mathrm{Q}_{1}=1.327+0.1 \overline{63}$ Cor_EnvPerf -0.041 Cor_CarEm $+\varepsilon$

Table 9. The Effect of Competitive Business Strategy on the Corporate Environmental Performance and Corporate carbon strategies towards corporate carbon emission disclosure

$\mathrm{Q}_{2}=\alpha 0+\beta 1$ Cor_EnvPerf $+\beta 2$ Cor_CarEm $+\beta 3$ Comp_BusStra $+\beta 4$ Cor_EnvPerf*Comp_BusStra $+\beta 5$ Cor_CarEm*Comp_BusStra $+\varepsilon$

\begin{tabular}{|c|c|c|c|c|}
\hline \multirow{3}{*}{ Variables } & \multirow{4}{*}{ Prediction } & \multicolumn{3}{|c|}{ Model 2} \\
\hline & & \multicolumn{3}{|c|}{ Corporate Financial Performance } \\
\hline & & Coefficients & p-value & Hypotheses Status \\
\hline Cons & & 2.321 & 0.001 & \\
\hline Cor_EnvPerf & + & 0.059 & $0.005 * *$ & Significant ( $\mathrm{H}_{1}$ support $)$ \\
\hline Cor_CarEm & + & 0.231 & $0.147 * *$ & Significant ( $\mathrm{H}_{2}$ not support) \\
\hline Comp_BusStra & + & 0.283 & $0.000 * *$ & Significant \\
\hline Cor_EnvPerf*Comp_BusStra & + & 0.795 & $0.012 * * *$ & Significant $\left(\mathrm{H}_{3}\right.$ support $)$ \\
\hline Cor_CarEm*Comp_BusStra & + & 0.982 & $0.077 * * *$ & Significant ( $\mathrm{H}_{4}$ not support) \\
\hline Adjusted R2 & & 0.710 & & \\
\hline F-Statistic & & 27,590 & & \\
\hline Prob (F-Statistic) & & $0.000 * * *$ & & \\
\hline Number of Observation & & 54 & & \\
\hline
\end{tabular}

***Significant at a level of 1 percent; **Significant at a level of 5 percent; *Significant at a level of 10 percent

Note: $Q_{1}$ : corporate carbon emission disclosure; Env_Awe: environmental awareness; Cor_Cas: corporate carbon strategies.

The Result of Hypotheses 3 and Hypotheses 4

$\mathrm{Q}_{2}=\alpha_{0}+\beta_{1}$ Env_Awe $+\beta_{2}$ Cor_Cas $+\beta_{3}$ Car_Know $+\beta_{4}$ Env_Awe*Car_Know $+\beta_{5}$ Cor_Cas*Car_Know $+\varepsilon$

$\mathrm{Q}_{2}=2.321+0,059$ Cor_EnvPerf $+0,231$ Cor_CarEm + ${ }_{-}^{-} 0,283$ Comp_BusStra $+0,795$

Cor_EnvPerf*Comp_BusStra $+0, \overline{9} 82$ Cor_CarEm*Comp_BusStra $+\varepsilon$

Table 4 shows that the interaction between corporate environmental performance and corporate financial performance with the competitive business strategy as a moderating variable has significant interaction (Hypothesis 3 is supported). This means that the competitive Business Strategy weakness the effect of corporate environmental performance towards corporate financial performance. These results support Soewarno (2018). Table 4 also show that the interaction between corporate carbon emission disclosure and corporate financial performance with the carbon reduction knowledge as a moderating variable have not significant interaction 
(Hypothesis 4 is not supported). This means that the corporate carbon emission disclosure weakness the effect of environmental awareness towards corporate carbon emission disclosure. These results not support Al-Rdaydeh (2018) which explains that the competitive business strategy of the firm is not a factor that can limit the chance of managers in doing corporate competitive business strategies activity.

\section{Conclusions, Implications, Limitations and Future Research Conclusions and Implications}

This research contributes to provide the corporate environmental performance literature, corporate carbon emission disclosure literature, and corporate financial performance literature. The results of this research show that: (i) corporate environmental performance has a positive and significant effect towards the corporate financial performance; (ii) corporate carbon emission disclosure has not a significant effect towards the corporate financial performance; (iii) competitive business strategy strengthens the effect of corporate environmental performance towards the corporate financial performance; (iv) competitive business strategy has not effect of corporate carbon emission disclosure towards the corporate financial performance.

It implies that by using data analysis for three years from 2015 to 2017 towards 18 companies (54 observation) and analyzing the data to the formula that is determined, it was found that in 2017, it was proved that government had done in 2017 governments in developing countries, especially in Indonesia, have begun to implement regulations for public companies listed on exchanges in Indonesia are required to publish sustainability reports, where in the report there are several sections regarding disclosure of corporate carbon emissions.

This research is considered important by research for now to several reason that are in accordance with the commitment of the government which states to commit to efforts to reduce carbon emission. This study contributes significantly of carbon emission, who want to see whether the effort to reduce carbon emission will have an impact on the corporate financial performance. In this study also, with the competitive business strategy carried out by the company. In Indonesian's companies that have made an awareness of their environmental will further strengthen the company's environmental performance on the corporate financial performance, with increasing corporate profit as a proxy for corporate financial performance.

\section{Limitations and Future Research}

The research only used sample of public companies in Indonesia as a developing country, so that the result cannot be generalized. it would be nice in this study used a sample of developing countries not only from Indonesia, but also other developing countries in the world that this research will be more varied.

In this study only uses the factors that influence the corporate financial performance as follows: corporate environmental performance awareness, corporate carbon emission disclosure and competitive business strategy. Meanwhile, in addition to these factors there again there are other factors that affect the corporate financial performance. Perhaps the next study can be used in addition to the three factors that have been used in this study.

\section{References}

Al-Rdaydeh, M., Almansour, A.Y., and Al-Omari, M.A. (2018), "Moderating effect of competitive strategies on the relation between financial leverage and firm performance: Evidence from Jordan", Business and Economic Horizons Journal, Vol 14 (3), pp. 626-641. ISSN: 1804-5006.

Angelia, D. and Suryaningsih, R. (2015). "The Effect of Environmental Performance And Corporate Social Responsibility Disclosure Towards Financial Performance (Case Study to Manufacture, Infrastructure, And Service Companies That Listed At Indonesia Stock Exchange)". Procedia - Social and Behavioral Sciences Volume. 211, pp.348 - 355

Bai, Y. and Liu, Y. (2013), "An exploration of residence low-carbon awareness and behavior in Tiajin, China", Energy Policy Journal, Vol.61, pp. 1261-1270.

Boaventura, J.M.G., da-Silva, R.S., dan de-Mello, R.B. (2012). "Corporate Financial Performance and Corporate Social Performance: Methodological Development and the Theoretical Contribution of Empirical Studies". R. Cont. Financial. - USP, São Paulo, Volume.23 (60), pp. 232-245.

Cai, J., Le, N., Oktavius, F.E., Nguyen, T.T., Roxas, S.C. (2014), "Environmental and financial performance: The virtuous cycles of Japanese manufacturing companies", Asia Pacific Business \& Economics Perspectives, 2(1), pp. 71-77.

CDP Global Climate Report, (2015), “CDP Global Climate Change Report 2015. Carbon Disclosure Project. https://www.cdp.net/CDPResults/CDP-global-climate-change-report-2015.pdf.

Camilleri, M.A. (2015), "Environmental, social and governance disclosure in Europe", Sustainability Accpunting, Management and Policy Journal, Vol.6 issue 2, pp. 224-242

Choi,B., Lee, D. \& Psaros, J. (2013), An analysis of Australian company carbon emission disclosures. Pacific Accounting Review Vol.25 (1), pp. 58-79.

Deegan, C., Rankin, M. and Tobin, J. (2002), “An examination of the corporate social and environmental 
disclosure of BHP from 1983-1997: A test of legitimacy theory," Accounting, Auditing \& Accountability Journal, Vol.15 No.3, pp. 312-343.

Evangelinos, K., Nikolao, I. and Leal, F.W. (2015), "The effect of climate change policy on the business community: a corporate environmental accounting perspectives", Corporate Social Responsibility and Environmental Management journal.

Fenster, M. (2015), "Transparency in search of a theory”, European Journal of Social Theory, Vol.18 No.2, pp. $150-167$

Ghozali, I (2013). Aplikasi Analisis Multivariete dengan Program IBM SPSS 23. Edisi Kedelapan: Penerbit Universitas Diponegoro.

Ghozali, I. (2016). Aplikasi Analisis Multivariate dengan Program IBM SPSS19, Badan Penerbit Universitas Diponegoro, Semarang.

Ghomi, Z.B. and Leung, P. (2013), "An empirical analysis of the determinants of greenhouse gas voluntary disclosure in Australia”, Accounting and Finance Research, Vol.2 (1), pp. 110-127.

Giacomo, N.D., Githrie, J. and Farneti, F. (2017), "Environmental management control system for carbon emission", PSU Research Review, Volume 1 (1), pp. 39-50.

Gonzales, J.M. and Remirez, C.Z. (2016), "Voluntary carbon disclosure by Spanish companies: an empirical analysis", International Journal of Climate Chane Strategies and Management, Vol.8 (1), pp.57-79.

Halm, R., Reimsbach, D. and Schiemann, F. (2015), "Organizations, climate change, and transparency: Reviewing the literature on cabon disclosure", Organization \& Environmental Journal, Vol. 28 Issue 1, pp. 80-102.

Hsu, J.L. and Lin, T. (2015), "Carbon reduction knowledge and environmental consciousness in Taiwan", Management of Environmental Quality: An International Journal, Vol. 26 Issue 1, pp. 37-52.

Iwata, H. and Okada, K. (2010), "How does environmental performance Affect financial performance? Evidence from Japanese manufacturing firms", MPRA Paper, No. 2772, pp. 1-27.

Jayanthi, K. \&Jubb, C. (2016). Carbon emission risks and management accounting: Australian evidence. Accounting Research Journal, Vol. 29 (2), 1-23.

Jeswani, H.K., Wehrmeyer, W. and Mulugetta, Y. (2008), "How warm is the corporate response to climate change?, Evidence from Pakistan and the UK, Business Strategy and the Environmental Journal, Vol.18, pp. 46-60.

Jiang, W. and Chen, X. (2016), "Optimal strategies for manufacturing with strategiec customer behavior under carbon emission sensitive random demand”, Industrial Management \& Data Systems, Vol. 116 Issue 4, pp.759-776.

Jiang, L., Yang Q, and Dellestrand, H. (2017). "The Relationship between Corporate Social and Financial Performance: Evidence from Chinese Heavy-polluting Industries: Journal Master Thesis Uppsala University, Volume 3, pp. 01-53.

Kementerian Lingkungan Hidup. (2017). Laporan Hasil Penilaian Program Peringkat Kinerja Perusahaan Dalam Pengelolaan Lingkungan Hidup 2010. Jakarta : Badan Penerbit Kementerian Lingkungan Hidup.

Kementerian Lingkungan Hidup. (2016). Laporan Hasil Penilaian Program Peringkat Kinerja Perusahaan Dalam Pengelolaan Lingkungan Hidup 2011. Jakarta : Badan Penerbit Kementerian Lingkungan Hidup.

Kementerian Lingkungan Hidup. (2015). Laporan Hasil Penilaian Program Peringkat Kinerja Perusahaan Dalam Pengelolaan Lingkungan Hidup 2012. Jakarta : Badan Penerbit Kementerian Lingkungan Hidup.

Kumarasiri, J. and Jubb, C. (2016) "Carbon emission risks and management accounting: Australian evidence", Accounting Research Journal, Vol. 29 (2), pp.137-153.

Li, X., Cui, X., and Wang, M. (2017), “Analysis of China's Carbon Emission Base on Catbon Flow in Four main Sectors: 2000-2013”, Sustainability Journal, Vol.10, pp. 1-13

Luo, L., Tang Q. and Lan Y.C. (2013), "Comparison of Prospensity for carbon disclosure between developing and developed countries", Accounting Research Journal, Vol. 26 (1), pp. 16-34.

Manrique, S. and Ballester, C.P.M. (2017). "Analyzing the Effect of Corporate Environmental Performance on Corporate Financial Performance in Developed and Developing Countries". Sustainability Journal Vol. 9, pp. $1-30$.

Mirza Rizkan, M., Islahuddin, dan Nadirsyah. (2017). "Pengaruh kinerja lingkungan dan pengungkapan lingkungan terhadap kinerja keuangan perusahaan pertambangan dan pemegang HPH/HPHTI yang terdaftar di Bursa Efek Indonesia”. Jurnal Magister Akuntansi Pascasarjana Universitas Syiah Kuala ISSN 2302- 0164.

Paul, A., Lang J.W.B., and Baumgartner, R.J. (2017), "Multilevel approach for assessing business strategies on climate change", Journal of Cleaner Production 160, pp. 50-70. www.elsevier.com/locate/jclepro.

Porter, M.E. \& Linde, C. (1995), "Green and competitive: Ending the statement. Harvard Business Review. Vol. 28 No. 6, pp. 126-129.

Porter, M.E. (1996), "What is strategy?" Harvard Business Review, November-December.

Rahman, R.N.A., Rasid, S.Z.A., and Basiruddin, R. (2014), "Exploring the relationship between carbon performance, carbon reporting, and firm performance: A conceptual paper", Procedia - Social and Behavioral Sciences, Vol. 164, pp. 118 - 125. 
Rahimi, J. (2016), "The Effect of Business Strategies on the Relationship between Leverage Relative and Financial Performance of Listed Companies in Tehran Exchange”, Information and Knowledge Management, Vol. 6 (2), pp. 17-26. ISSN 2224-5758 (paper). ISSN 224-896X (online).

Renukappa, S. and Suresh, S.S. (2008), "Managing knowledge associated with carbon reduction initiatives", The Green Contruction Board, Vol.1, pp. 1-4.

Spencer, S. Y., Adams, C., and Yapa, P. W. S. (2013). "The Mediating Effects of the Adoption of an Environmental Information System on Top Management's Commitment and Environmental Performance”. Sustainability Accounting, Management and Policy Journal. Vol 4 (1), pp. 75-102.

Sudibyo, Y.A. (2018), "Carbon emission disclosure: does it matter", IOP Conf. Series: Earth and Environmental Science, Vol. 106, pp. 1-6.

Sullivan, R. and Gouldson, A. (2015), "Comparing the climate change actions targets and performance of UK and US retailers", Corporate Social Responsibility and Environmental Management Journal , available at: http://onlinelibrary. wiley.com/journal/ 10.1002/ISSN.1535-3966/earlyview

Zailani, S. H. M., Eltayeb, T. K., Chin-Chun Hsu \& Keah Choon Tan. (2012). The Impact of External Institutional Drivers and Internal Strategy on Environmental Performance. International Journal of Operations \& Production Management. Vol. 32 No. 6, pp. 721-745.

Zanella, A., Camanho, A.S. \& Dias, T.G. (2013). Benchnarking countries' environmental performance. Journal of the Operational Research Society 64, pp. 426-438. 